\title{
Digital Readiness for Social Educators in Health Care and Online Learning During COVID-19 Pandemic: A Bibliometric Analysis
}

\author{
https://doi.org/10.3991/ijim.v15i18.25529 \\ Nguyen Thuy $\operatorname{Van}^{1(凶)}$, Alhamzah F. Abbas ${ }^{1}$, Hassan Abuhassna ${ }^{1}$, \\ Fareed Awae ${ }^{1}$, Daniel Dike ${ }^{2}$ \\ ${ }^{1}$ Universiti Teknologi Malaysia (UTM), Johor, Malaysia \\ ${ }^{2}$ STKIP Persada Khatulistiwa Sintang, West Kalimantan, Indonesia \\ thuyvannguyen@utm.my
}

\begin{abstract}
Digital technologies have been earsplittingly discussed for a long time with multi-sides of enormous benefits and challenges in educational application. When the Covid19 pandemic has outbreak worldwide, global governments have popularly employed the movement control order (MCO) and social distances policies, international borders closed, schools and higher education applied for fully online courses. Several studies show that digital readiness is the crucial factor that significantly impacts students' satisfaction and success in online learning. This study will analyze the overall resources and digital readiness in multi-sides to enhance student learning and development outcomes through an online learning environment. To reach the objectives, the literature accessed of Scopus and web of science databases. The systematic review employed and the finally adapted criteria 32 articles are selected. The bibliometric analysis will conduct for to identify the cluster themes based on texting frequency. The process of vital steps of data classification follow seriously and carefully in platform of concept, findings, author's reputation and years published. In the last findings of the study, reports will explain past literature and recent outbreak. The findings cover three main themes: digital readiness in learning management, digital readiness for learners, and digital readiness for educators. During the covid19 pandemic, the concept of digital readiness for educators concealed in both healthcare advising and lesson teaching in home-based learning models. These findings are expected to benefit stakeholders involved in online teaching and learning during and resilient post-Covid-19 pandemic.
\end{abstract}

Keywords-Digital readiness, COVID-19, student development and success

\section{$1 \quad$ Introduction}

Although review witness of many studies' findings of digital education is the best way to awareness enrichment, flexible and saving cost for diverse learners in the 21st century [1], however, others show the rate of students graduates in online learning 
lower than students join in physical classes [2]. This mix-findings raise questions for higher education institutions to support students overcoming online learning challenges to reach their own targets and adapt to the digital economic environment with high requests daily. Reviews indicated digital environment requires some standard maneuvers to engage and ensure students adapting the online learning environment. Among these, digital readiness has been an effective strategy in enhancing student learning achievements [3]. Digital readiness has been described in different sides in reviews. Some studies concern readiness for students to be equipped before they join online courses to adapt to the online learning environment. A few studies mentioned digital readiness for teachers/educators. During the Covid19 pandemic, students have been forced to join online courses; students must study online without other options for being safe and need to stay at home. Using big data analytics to ensure that the benefits of digital preparedness on student performance are adequately responsive during the Covid19 pandemic, this paper designated involved papers for assessments by biometric analysis to explore emerging themes for enlightening and argument [4]. This paper's structure of digital readiness consists of a learning management system, learners, and educators.

\section{$2 \quad$ Materials and methods}

The reviews and meta-analysis technique was employed for the systematic literature review (S.L.R.) [5]. The PRISMA statement template describes the overall research process to select and reject articles in the process. This S.L.R. base study is limited to published literature on the topic of digital readiness. The two databases, the web of science and Scopus, are using for the literature extraction. The database's total results are 689 when using keywords of "Digital Readiness" AND "COVID-19" in the search bar.

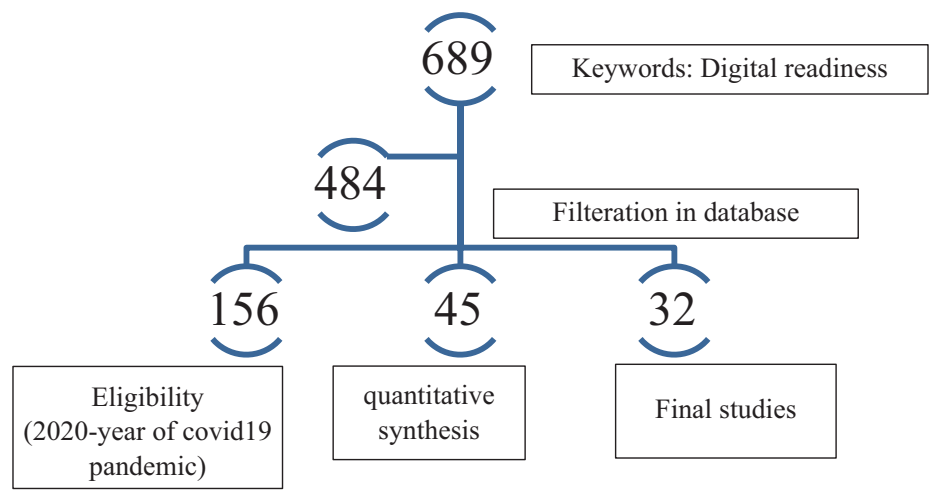

Fig. 1. PRISMA statement 2015

The results are narrow down to 484 in the process; then continually narrowed down to 156 when limited years $(2019,2020)$, and after removing the duplication, and irrelevant literature, the final 32 studies are included for the review. Figure 1 is showing the detailed process of data selection. 


\section{$3 \quad$ Results}

\subsection{Descriptive analysis}

The study is converging on digital readiness for online learning in the pandemic outbreak. Figure 2 shows the dramatically increasing number of papers from 2020 and 2021 base graph of literature. The year 2020 contributing the highest number with 148 , rises of triple time with (44 papers) in 2015 and 10 times with 15 papers in 2010 .

\section{Documents by year}

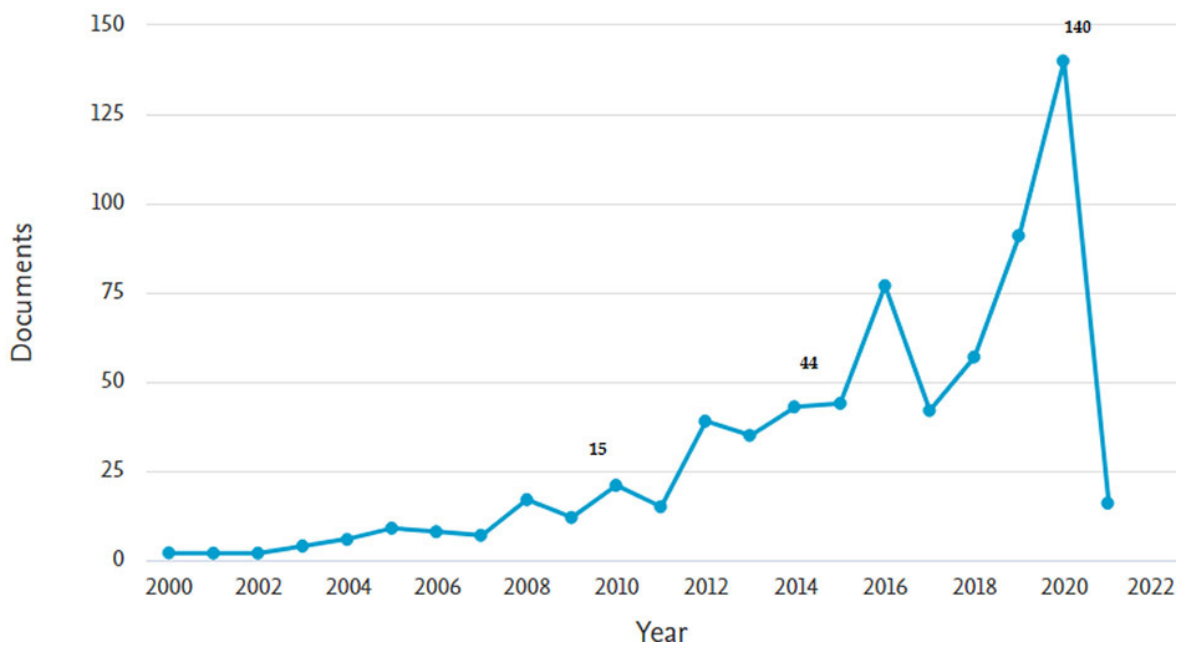

Fig. 2. Number of studies from each year (Source: Scopus.com, access in Feb 2021)

Observably, United States' holder of highest studies on digital readiness with 179 articles, Australia reached the second high number with 70 articles, and Malaysia has arranged the third place with 59 articles. Classify of research fields, 03 research areas attracted the majority of papers are social sciences receive highest number $416(34,5 \%)$ Computer science 280 (23,2\%); Engineering 109 (9,0\%).
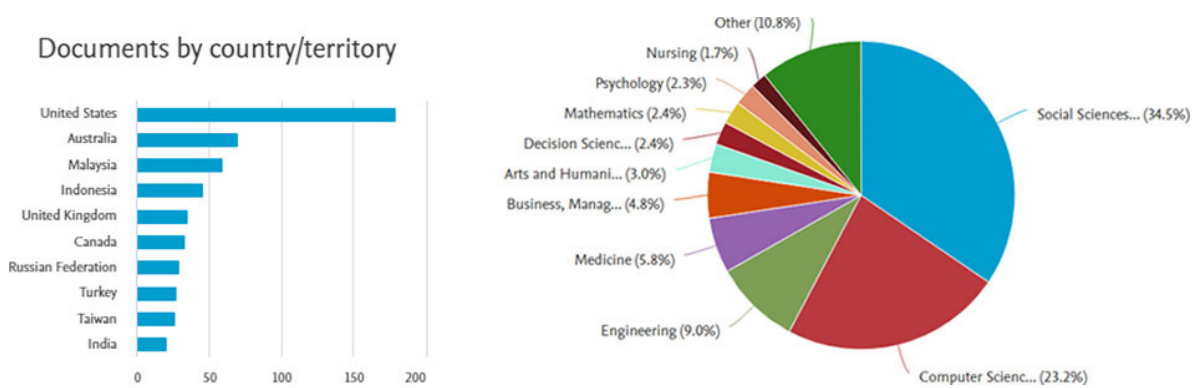

Fig. 3. Country and research field base publication 
Furthermore, the high number of citations was criteria to select for the current study and finds; list of 10 Journals were show in the map, such as Computer and Education; International Review of Research in Open and Distance Learning, International Journal of Educational Technology in Higher Education; etc. attractive in authors whole the world.

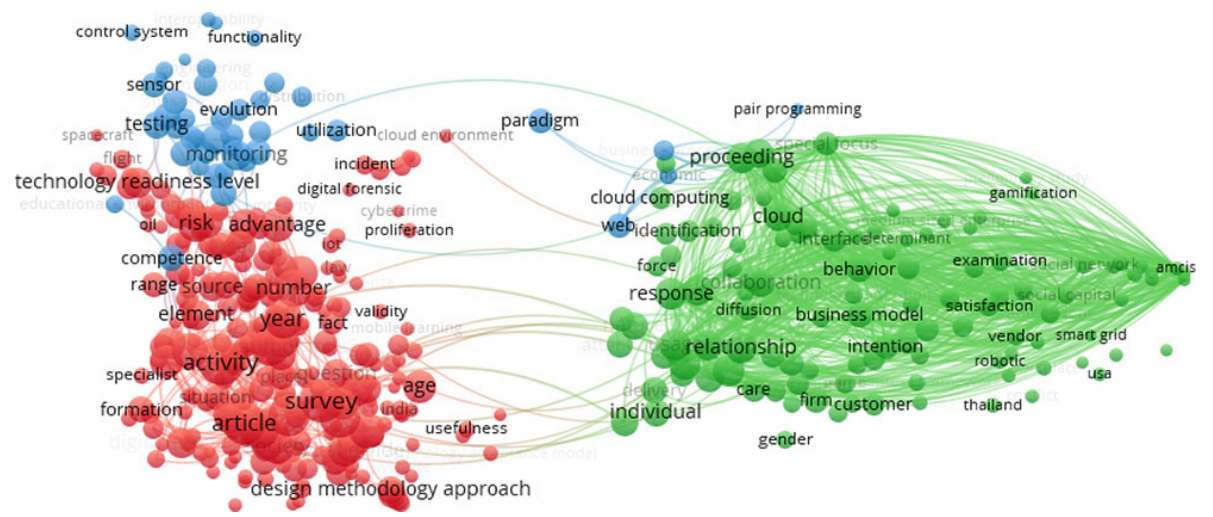

Fig. 4. Bibliometric analysis with keywords "digital readiness for online learning" with 851 articles in scopus database, accessed in Feb. 2021

In early years of the 21 st century, the review shows a considerable number of studies emphasized the trends of the fourth industry revolution (IR4.0) affected education and bring enormous benefits for student outcome when readiness for digital education is enthusiastic concerned and healthy system development. The next cluster of keywords demonstrates that subject has been continuously conversed in this part of the article, see Figure 4. Review show three dimensions to determine for digital readiness might be classified into three groups, learning management system, learner, and teacher/instructor readiness.

\subsection{Learning management systems}

According to Emelyanova \& Voronina (2014), learning management systems (L.M.S.) or "virtual learning system" is the crucial key for stakeholders involve success and satisfy when providing a constructive approach to awareness achievement and support dynamic learning. Fung Kee Fung et al., (2000) argued that the Internet-based, multi-user, multi-center learning portfolio significantly affects residents' significantly higher perception. Furthermore, universities were pioneers in investing in virtual learning systems to ensure distance learning accessibility in synchronous and asynchronous styles, along with the tremendous development of internet technologies and subsequent digital equipment in diversity in both hard and soft products that provide opportunities for universities in learning management system readiness [8]. The digital readiness mainly supports stakeholders in enhancing their perceptions and how to use the system's convenience, effectiveness, and usefulness [6]. Although the gap in 
quantity and quality between or between developed and developing countries is not the same, however, most studies indicated that the urgent need to equip digital system readiness in web-based learning or distance education, e-learning, online learning; in inconvenience, effectiveness, and usefulness (Hishan et al., 2021; N Emelyanova \& Voronina, 2014).

\subsection{Digital readiness for learners}

The next point with much discussed in the reviews is student's readiness with digital education. [9] classified student readiness as essential readiness, skills readiness, psychological readiness, and budget readiness. Other studies emphasized that learner characteristics, digital divide, information and communications technology, and engagement are readiness factors for online learners; developed and validated the instrument to measure student readiness for online learning (Lowenthal, 2011), in which the component of learner characteristics, digital divide, information and communications technology (I.C.T.) engagement.

In general, students welcome the incorporation of mobile learning in education, they are highly acquainted with computing skills. However, apart from the software and hardware, the telephone line and Internet line were challenges facing with requirements stakeholder in support.

Most studies assumed that there was a significant correlation between student readiness and satisfaction (Akhtar et al., 2021); readiness students show great ready skills and positive intentions towards the system for their web-based learning activities and expose a potential benefit from its use in the long term; they feel comfortable with e-1 learning (Smith et al., 2003). Digital readiness was a significant correlation with students learning achievements. There was a strong link between digital readiness and student learning outcomes. Students were successful in online learning, with solid skills in computer/Internet self-efficacy, motivation, self-directed learning (Krish et al., 2012), learner control, and online communication self-efficacy. According to reviews, Digital Media Simulations effectively increased student engagement and promoted deeper learning (Beckem \& Watkins, 2012). As a result of the trends, Pillay et al., (2007) discovered that young learners are more comfortable with technical skills and computer self-efficacy and that digital preparedness should focus on students' structure knowledge skills. This outcome was overwhelmingly positive.

Previous research has shown that students who enter online learning without being well prepared have poor confidence, high anxiety, low perceived competence, and a weak willingness to communicate; inept practice [11], [12] pointed out that technological facilitating conditions are factors that significantly affect student's perceived readiness comfort with e-Learning, while full-online distance learning, financial ability, self-competence, uncertainty avoidance were challenges for student.

Nonetheless, "digital readiness" has emerged as a critical component for the current success of digital education and future trends toward effective student outcomes in performance and satisfaction. As a result, colleges must provide students with digital readiness training before enrolling in an online course [13]. 


\subsection{Digital readiness for educator during Covid 19 pandemic}

\begin{tabular}{|c|c|}
\hline Authors & Findings \\
\hline $\begin{array}{l}\text { Bokayev B., Torebekova Z., } \\
\text { Abdykalikova M., } \\
\text { Davletbayeva Z. (2021) } \\
\text { The U.S. }\end{array}$ & $\begin{array}{l}\text { Readiness is facing many issues: weak internet infrastructure and a } \\
\text { lack of effective interaction with all stakeholders. } \\
\text { Factor:- an exciting citizenry and committed teachers - show that } \\
\text { considerably more work has to be put into bringing "best practices" } \\
\text { from developed countries to developing ones. }\end{array}$ \\
\hline $\begin{array}{l}\text { Juwita R., Siswandari, } \\
\text { Joyoatmojo S., Wiranto (2020) } \\
\text { - (Indonesia) }\end{array}$ & $\begin{array}{l}\text { School principals play an essential role in developing high-performing } \\
\text { schools-show that OMaPro positively influenced the cognitive, } \\
\text { behavioral, and emotive-attitude readiness of the participants. } \\
\text { Unfortunately, the program cannot run in rural areas because of the } \\
\text { lack of internet access. }\end{array}$ \\
\hline $\begin{array}{l}\text { Khan M.A., Vivek, Nabi M.K., } \\
\text { Khojah M., Tahir M. (2021) }\end{array}$ & $\begin{array}{l}\text { Educators using social media may engage and further improve the } \\
\text { learning output in the new learning system. }\end{array}$ \\
\hline $\begin{array}{l}\text { Zhang H., Huang T., Liu S., } \\
\text { Yin H., Li J., Yang H., } \\
\text { Xia Y. (2020) (Chinese) }\end{array}$ & $\begin{array}{l}\text { Educators design online lesson propose a learning style classification } \\
\text { approach based on the deep belief network (DBN). }\end{array}$ \\
\hline $\begin{array}{l}\text { Kabir M.R. (2020) } \\
\text { (Bangladesh) }\end{array}$ & $\begin{array}{l}\text { Effect of technology adoption intention and the private universities } \\
\text { are well ahead of providing online education the mindset to adopt } \\
\text { technology-based virtual learning while the public university } \\
\text { stakeholders are yet to initiate it. }\end{array}$ \\
\hline $\begin{array}{l}\text { Pavan Kumar S. (2021) } \\
\text { (India) }\end{array}$ & $\begin{array}{l}\text { Educators equip digital learning skills for students to learn satisfied and } \\
\text { avoid distracting social media. }\end{array}$ \\
\hline $\begin{array}{l}\text { Kaushik M.K., Agrawal D. } \\
\text { (2021) (India) }\end{array}$ & $\begin{array}{l}\text { Educators design online platforms, presenting in interaction with } \\
\text { digital technology, engagement among students during teaching for } \\
\text { enhancement of achieving excellence. }\end{array}$ \\
\hline $\begin{array}{l}\text { El Refae G.A., Kaba A., } \\
\text { Eletter S. (2021) }\end{array}$ & $\begin{array}{l}\text { Covid19 pandemic provides opportunities and advantages of distance } \\
\text { learning. Students can interact with global friends in a different zone } \\
\text { with the same topic. }\end{array}$ \\
\hline $\begin{array}{l}\text { The N.A.A., Naing L. } \\
\text { (2021) London - U.K. }\end{array}$ & $\begin{array}{l}\text { Educators should apply online assessment: online quizzes, } \\
\text { multiple-choice questions, continuous feedback, and automated essay, } \\
\text { self-test quiz, the online tools: feedback, and discussion forums } \\
\text { with auto assessment and deadline management. }\end{array}$ \\
\hline $\begin{array}{l}\text { Kriewaldt J., Walker R., } \\
\text { Morey V., Morrison C. } \\
\text { (Australia) }\end{array}$ & Using video and feedback for teaching, perform an assessment. \\
\hline $\begin{array}{l}\text { Palaoag T.D., Catanes J.G., } \\
\text { Austria R., Ingosan J.S. (2020) } \\
\text { (Phillipine) }\end{array}$ & $\begin{array}{l}\text { H.E.I. should develop a flexible learning organization for online } \\
\text { distance learning to attain excellence education. H.E.I.s should develop } \\
\text { their framework for continuous learning anchored on the current } \\
\text { tools and resources of the institution, proficiency of staff and faculty } \\
\text { members, and capacity of students. }\end{array}$ \\
\hline $\begin{array}{l}\text { Zha S., Moore P., Browning B., } \\
\text { Fetner J., Ortiz Y.L. } \\
\text { Looi C.-K., Chan S.-W., } \\
\text { Wu L. (2021) }\end{array}$ & $\begin{array}{l}\text { Team-based learning (TBL) is a type of small-group collaborative } \\
\text { learning that promotes students' accountability and intellectual growth } \\
\text { in online learning. Educators promote students the great potential of } \\
\text { addressing the widespread course preparation problem, given enough } \\
\text { attention to exploring and creative in learning and effectiveness of the } \\
\text { readiness assurance stage in online. }\end{array}$ \\
\hline
\end{tabular}


Since the Covid-19 pandemic spread worldwide in the early year 2020, faceto-face classes have temporarily closed to prevent the coronavirus outbreak [14]. The world has witnessed school closure in 192 countries and the consequence of over 1.5 billion affected students registered from pre-primary to upper secondary and tertiary education levels. Reviews show that most educational institutions have shifted online learning quickly and students have encouraged stay at home to continue learning through a digital platform for achievements [15]. The compulsory online learning at home with students in differences of background and context; many fears of with much worries of covid19 pandemic in society worldwide have many challenges. The challenges facing in most of the places are such as anxiety of pandemic threaten in healthcare; lack of innovative digital equipment (laptop, computers, phone); poor internet connection when all student using in the exact times or confused with blending materials resources; uncomfortable with digital skills weak online learning management \& poor teaching experiences [16]. Based on these challenges, this paper reviews the impact on educators' digital readiness practices to find out solutions to overcome challenges and continue to support students in healthcare and learning achievements.

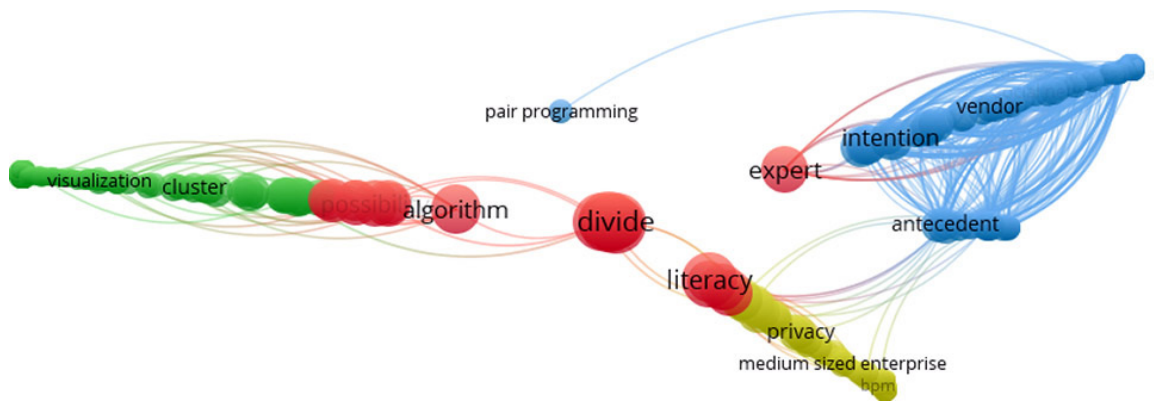

Fig. 5. Biblometric result of abstracts and keywords of digital readiness for online teaching and learning

\subsection{Digital readiness for educators in remote healthcare advising}

The reviews show several studies related to the impact of COVID-19 on students' mental health. The general findings illustrate that students significantly experience higher levels of anxiety, suffering, depression, and stress when compared with students during regular times, i.e., before the pandemic [17]. The leading causes of students' anxiety due to Covid19 could be classified as a general fear of isolation by lockdown, increasing number of deaths by Covid19 worldwide evolution to online classes, and reduction in study assistance and worry for one's future career [18]. 


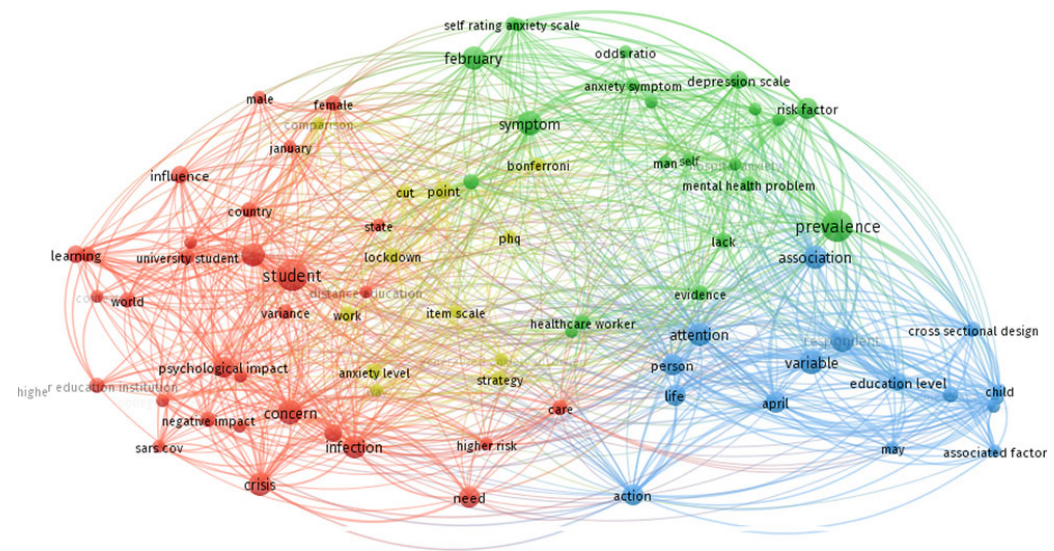

Fig. 6. Covid19 factors affected students' anxiety - bibliometric analysis from

In this case, the review shows that educators take a big jump to immediately employ online to connect with students, quickly move to online advising in healthcare, mental care, and digital teaching and learning [19]. Besides regular contact like a phone call, what sap, Facebook, integrate, Educators, need to quickly equip digital using knowledge and skills, such as zoom, google meet, and Webex to contact diverse students with different contexts [20].

Online Tools used by FSSH Academic Staff

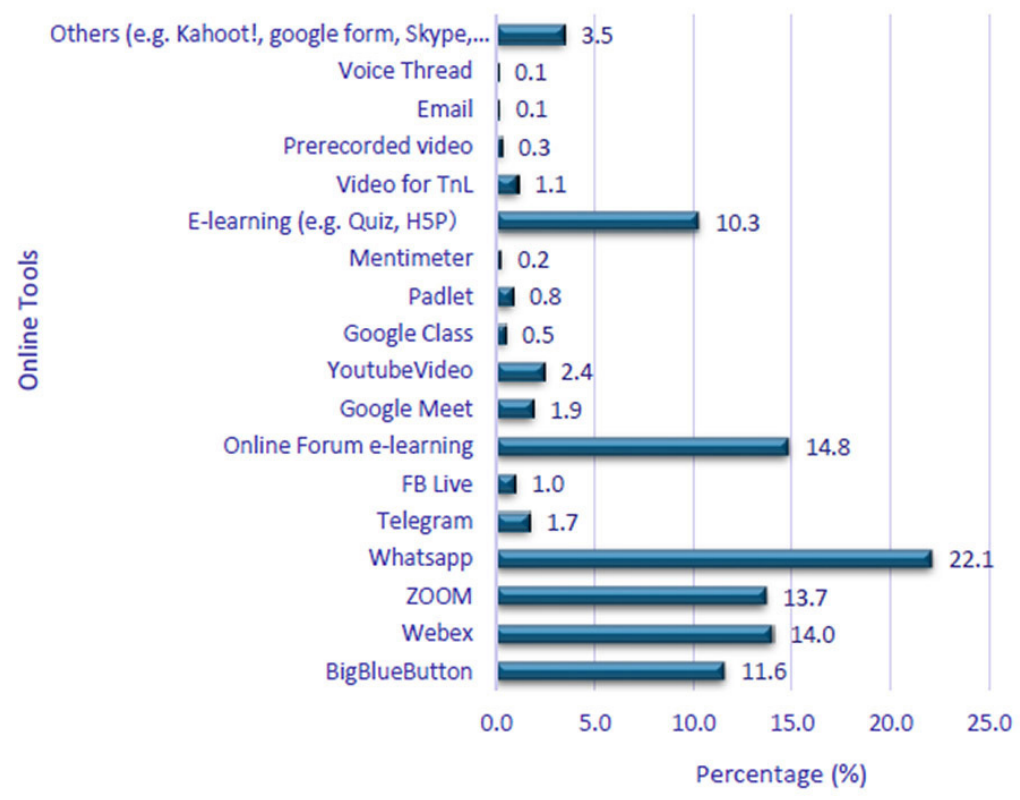

Fig. 7. Online tools used by academic staff

Source: A Report of FSSH UTM's experiences towards digitizing education 2020 
In the pandemic, especially with tiny children in primary and kindergarten courses, they must be cared for at home by family while their parents work from home; they are too young to learn basic skills and be digitally ready for online learning [21]. In this scenario, educators actively communicate with students' parents in order to share knowledge and pedagogy and to ensure that kids are adequately cared for in terms of physical and psychological health, as well as to encourage the use of home-based learning during the pandemic [22]. Bokayev et al., (2021)found that in the initial pandemic, committed teachers have put into bringing "best practices" from developed the relationship with the parents to support young learners while the authority community slowly to have a good policy.

\subsection{Digital readiness for educators in social online teaching}

When online education shift on almost all schools worldwide due to protecting learners at home by corona speedy breakout, reviews indicated that the pandemic might not affect eco-social life in a short time, and online education will remain persistent and widespread in the new norm for various education levels and access to multiple generations as the trends [24]. However, in the initial period, the barriers of home-based learning come across all over the poor internet connection and teachers' and students' lack of appropriate digital skills, especially teachers less confident in digital pedagogy in online learning [25]. Teachers seemed to show some of their fears of online teaching and a essential for the modernization of distance-education methods, variations in pedagogical activity and task structure for mentors and learners, and motivational and affective variables [26].

Review shows that many educational institutions correlated well with the digital readiness of the learning management system before setting up virtual classrooms and collaboration platforms [27]. The digital education system can convey and powers in transition knowledge to minimize the disruption of education on students and schools.

When applying online education setting in immediately from a face-to-face class. educators' roles have changed; they now have less influence over the learning process and more of a supportive role as "designers and facilitators." Providing instructional pedagogies in manipulative online learning for interactive technologies and guiding learners during the process, is a described simulation of online teaching [15]. Educators must be prepared to serve in a variety of roles in digital education, including technologist.

The teaching process typically consists of lesson structure, content presentation, collaboration and communication, and timely criticism; however, in online learning, the contents may be out of control by instructors. Due to the power of digital technology, which allows students access to global class materials; and collaboration and interaction may move outside of the classroom or across borders. Readiness of pedagogies for educator make sure the distant teaching can occur straightforwardly, and motivation and engagement students in self-explore and self-directed to meet their learning requirements and benefits; target their achievements not only curriculum goals as face to face class focus [28].

However, the online environment also provides vital to foster the students' distracted, prefer in playing games or reply to emails and social messages, while discount the school work and weak attention of lesson content. Educators should use the power of digital technology in learning assessment and time management when compared with teaching in class. For example, providing a course outline, auto-remind the student of the deadline of task or assignment, mange study results in each period, and 
give suggestions to improve and emphasized that mental health should be considered to ensure students exciting about studying through of motivation, relationships [29].

\section{Conclusion}

Digital Readiness plays a crucial factor significantly affect on online learning outcomes. Digital readiness mentions in the review three aspects, learning management system, learner readiness, and educator readiness. In the emergence of the Covid19 pandemic speedy outbreak, educators have contributed their efforts and knowledge in virtual environments to advise students in healthcare for safety, reduce anxiety, and continue studying through home-based learning. Reviews show that educators worldwide facing many challenges when entirely shift to online learning. Such as poor internet, students weak in digital readiness, and teacher lack of experience. Therefore, this paper's digital readiness review covers several aspects expected to bring benefits to online learning stakeholders.

\section{$5 \quad$ References}

[1] I. Mustapha, N. T. Van, M. Shahverdi, M. I. Qureshi, and N. Khan, "Effectiveness of Digital Technology in Education During COVID-19 Pandemic. A Bibliometric Analysis," Int. J. Interact. Mob. Technol., vol. 15, no. 8, pp. 136-154, Apr. 2021, doi: https://doi .org/10.3991/ijim.v15i08.20415

[2] W. Bao, "COVID-19 and online teaching in higher education: A case study of Peking University," Hum. Behav. Emerg. Technol., vol. 2, no. 2, pp. 113-115, Apr. 2020, doi: https://doi.org/10.1002/hbe2.191

[3] N. Khan, M. I. Qureshi, I. Mustapha, S. Irum, and R. N. Arshad, "A systematic literature review paper on online medical mobile applications in Malaysia," Int. J. Online Biomed. Eng., vol. 16, no. 1, pp. 63-82, Jan. 2020, doi: https://doi.org/10.3991/ijoe.v16i01.12263

[4] S. S. Hishan, M. I. Qureshi, N. Khan, S. Ramakrishnan, H. Jaiprakash, and Y. Vaicondam, "Impact of COVID-19 pandemic on sustainable development goals: What we learn from the past and where we are heading?," Estud. Econ. Apl., vol. 39, no. 3, pp. 30-47, Jul. 2021, doi: https://doi.org/10.25115/eea.v39i3.4172

[5] D. Moher et al., "Preferred reporting items for systematic reviews and meta-analyses: The PRISMA statement," PLoS Medicine, vol. 6, no. 7. Public Library of Science, p. e1000097, Jul. 2009, doi: https://doi.org/10.1371/journal.pmed.1000097

[6] N. Emelyanova and E. Voronina, "Introducing a learning management system at a russian university: Students' and teachers' perceptions," Int. Rev. Res. Open Distance Learn., vol. 15, no. 1, pp. 272-289, 2014, doi: https://doi.org/10.19173/irrodl.v15i1.1701

[7] M. Fung Kee Fung et al., "An internet-based learning portfolio in resident education: The KOALA(TM) multicentre programme," Med. Educ., vol. 34, no. 6, pp. 474-479, 2000, doi: https://doi.org/10.1046/j.1365-2923.2000.00571.x

[8] M. I. Qureshi, N. Khan, S. Qayyum, S. Malik, H. S. Sanil, and T. Ramayah, "Classifications of sustainable manufacturing practices in ASEAN region: A systematic review and bibliometric analysis of the past decade of research," Sustainability (Switzerland), vol. 12, no. 21. MDPI AG, pp. 1-19, Oct. 2020, doi: https://doi.org/10.3390/su12218950

[9] P. Krish, S. Hussin, M. R. Manap, and Z. Amir, "Mobile learning readiness among Malaysian students at higher learning institutes," Asian Soc. Sci., vol. 8, no. 12, pp. 276-283, 2012. https://doi.org/10.5539/ass.v8n12p276 
[10] B. J. Dray, P. R. Lowenthal, M. J. Miszkiewicz, M. A. Ruiz-Primo, and K. Marczynski, "Developing an instrument to assess student readiness for online learning: A validation study," Distance Education, vol. 32, no. 1, pp. 29-47, May 2011, doi: https://doi.org/10.1080/ $\underline{01587919.2011 .565496}$

[11] T. Levett-Jones, J. Gersbach, C. Arthur, and J. Roche, "Implementing a clinical competency assessment model that promotes critical reflection and ensures nursing graduates' readiness for professional practice," Nurse Educ. Pract., vol. 11, no. 1, pp. 64-69, 2011, doi: https://doi.org/10.1016/j.nepr.2010.07.004

[12] H. Pillay, K. Irving, and M. Tones, "Validation of the diagnostic tool for assessing tertiary students' readiness for online learning," High. Educ. Res. Dev., vol. 26, no. 2, pp. 217-234, 2007, doi: https://doi.org/10.1080/07294360701310821

[13] J. J. Downing and J. E. Dyment, “Teacher Educators' Readiness, Preparation, and Perceptions of Preparing Preservice Teachers in a Fully Online Environment: An Exploratory Study," Teach. Educ., vol. 48, no. 2, pp. 96-109, Apr. 2013, doi: https://doi.org/10.1080/ 08878730.2012 .760023

[14] B. Bokayev, Z. Torebekova, M. Abdykalikova, and Z. Davletbayeva, "Exposing policy gaps: the experience of Kazakhstan in implementing distance learning during the COVID-19 pandemic," Transform. Gov. People, Process Policy, vol. 15, no. 2, pp. 275-290, 2020, doi: https://doi.org/10.1108/TG-07-2020-0147

[15] C. K. Looi, S. W. Chan, and L. Wu, "Crisis and Opportunity: Transforming Teachers From Curriculum Deliverers to Designers of Learning," in Lecture Notes in Educational Technology, Springer Science and Business Media Deutschland GmbH, 2021, pp. 131-145. https://doi.org/10.1007/978-981-15-7869-4_9

[16] A. Wu et al., "Genome Composition and Divergence of the Novel Coronavirus (2019nCoV) Originating in China," Cell Host Microbe., vol. 27, no. 3, pp. 325-328, Mar. 2020, doi: https://doi.org/10.1016/j.chom.2020.02.001

[17] M. Abdessater et al., "COVID19 pandemic impacts on anxiety of French urologist in training: Outcomes from a national survey," Prog. en Urol., vol. 30, no. 8-9, pp. 448-455, Jun. 2020, doi: https://doi.org/10.1016/j.purol.2020.04.015

[18] H. Van Minh et al., "Self-reported non-communicable diseases and associated sociodemographic status among ethnic minority populations in Vietnam, 2019," Heal. Psychol. Open, vol. 7, no. 2, Jul. 2020, doi: https://doi.org/10.1177/2055102920954707

[19] N. Khan, M. I. Qureshi, I. Mustapha, A. A. Harasis, and M. Ashfaq, "The Digital Marketing Past, Present, and Future in Malaysia," J. Comput. Theor. Nanosci., vol. 17, no. 2, pp. 583-595, Apr. 2020, doi: https://doi.org/10.1166/jctn.2020.8732

[20] A. Gottscholl et al., "Initialization and read-out of intrinsic spin defects in a van der Waals crystal at room temperature," Nat. Mater., vol. 19, no. 5, pp. 540-545, May 2020, doi: https://doi.org/10.1038/s41563-020-0619-6

[21] Q. Xie et al., "Increase of High Molecular Weight Organosulfate With Intensifying Urban Air Pollution in the Megacity Beijing," J. Geophys. Res. Atmos., vol. 125, no. 10, p. e2019JD032200, May 2020, doi: https://doi.org/10.1029/2019JD032200

[22] S. Kim et al., "PubChem in 2021: New data content and improved web interfaces," Nucleic Acids Res., vol. 49, no. D1, pp. D1388-D1395, Jan. 2021, doi: https://doi .org/10.1093/nar/gkaa971

[23] B. Bokayev, Z. Torebekova, Z. Davletbayeva, and F. Zhakypova, "Distance learning in Kazakhstan: estimating parents' satisfaction of educational quality during the coronavirus," Technol. Pedagog. Educ., vol. 30, no. 1, pp. 27-39, 2021, doi: https://doi.org/10.1080/1475 939X.2020.1865192

[24] A. Anim, Y. D. Prasetyo, and E. Rahmadani, "Experimentation of Problem Posing Learning Model Assisted of Autograph Software to Students' Mathematical Communication Ability in Terms of Student's Gender," J. Ilm. Peuradeun, vol. 7, no. 2, p. 331, May 2019, doi: https://doi.org/10.26811/peuradeun.v7i2.301 
[25] P. Pace, G. Aloi, R. Gravina, G. Caliciuri, G. Fortino, and A. Liotta, "An Edge-Based Architecture to Support Efficient Applications for Healthcare Industry 4.0," IEEE Trans. Ind. Informatics, vol. 15, no. 1, pp. 481-489, Jan. 2019, doi: https://doi.org/10.1109/ TII.2018.2843169

[26] M. I. Qureshi, N. Khan, S. M. Ahmad Hassan Gillani, and H. Raza, "A systematic review of past decade of mobile learning: What we learned and where to go," Int. J. Interact. Mob. Technol., vol. 14, no. 6, pp. 67-81, Apr. 2020, doi: https://doi.org/10.3991/ijim.v14i06.13479

[27] T. D. Palaoag, J. G. Catanes, R. Austria, and J. S. Ingosan, "Prepping the new normal: The readiness of higher education institution in cordillera on a flexible learning," in $A C M$ International Conference Proceeding Series, Jul. 2020, pp. 178-182, doi: https://doi.org/ $\underline{10.1145 / 3416797.3416829}$

[28] M. K. Looi, "Covid-19: Japan declares second state of emergency as Asia struggles with virus surge,” BMJ, vol. 372, p. n141, Jan. 2021, doi: https://doi.org/10.1136/bmj.n141

[29] J. A. G. de M. e. C. E Melo and N. M. F. Araújo, "Impact of the fourth industrial revolution on the health sector: A qualitative study," Healthc. Inform. Res., vol. 26, no. 4, pp. 328-334, 2020, doi: https://doi.org/10.4258/hir.2020.26.4.328

\section{Authors}

Nguyen Thuy Van is Vietnamese and holds a Ph.D. in Educational Management and Administration by Universiti Teknologi Malaysia and continues doing postdocs teaching and research at the school of Education. Her main area of interest is the study related to student development in personality, academic, social skills, and career improvement. She dedicated her Ph.D. thesis in academic advising in Malaysian public universities for student graduate on time and success and tries to explore the strengths and challenges in the Malaysian Higher education environment for local and international students. Her teaching fields are "pedagogy" in teacher training for undergraduates and "student development" for postgraduate students. She has over 10 articles published in Scopus journal related to academic advising, teaching, and learning. E-mail: thuyvannguyen@utm.my.

Alhamzah F. Abbas, Azman Hashim International Business School, Universiti Technologi Malaysia (UTM), 81310 Skudai, Johor, Malaysia. E-mail: alhamza.fadil@, gmail.com.

Hassan Abuhassna is currently working as an Assistant Professor at Universiti Teknologi Malaysia (UTM). He worked in UTM as a Postdoc fellowship for six months, as a part-time lecturer for two months, in addition to three years as research assistant. $\mathrm{He}$ is a Ph.D. holder in educational technology with Merit. In addition to a master's degree in Instructional Technology with practical experience. His research interest in MOOC, Elearning, and online learning, he has a total of 9 recent publications, two papers in WOS, in Q1 journals and Scopus indexed. he has 4 years of experience working in the field of education and multimedia training. E-mail: mahassan@utm.my.

Fareed Awae, School of Education, Faculty of Social Sciences and Humanities, Universiti Teknologi Malaysia (UTM), 81310 Skudai, Johor, Malaysia. E-mail: afareed@utm.my.

Daniel Dike, STKIP Persada Khatulistiwa Sintang, West Kalimantan, Indonesia. E-mail: dikedanieltukan@gmail.com.

Article submitted 2021-07-15. Resubmitted 2021-08-28. Final acceptance 2021-08-29. Final version published as submitted by the authors. 